\title{
Ways to increase the efficiency of the marketing activities of the advertising enterprises
}

\author{
Zolotarova Valentina ${ }^{1}$ \\ ${ }^{1}$ Postgraduate, Interregional Academy of Personnel Management
}

\begin{abstract}
The purpose of the article is to identify ways to improve the marketing activity of advertising companies. In the course of the research were used: general scientific methods, in particular: systematic approach - to identify and justify the global trends in the development of advertising services; expert survey method - to determine the priorities of advertising companies and promoters of promotional products among these two groups of respondents in the process of interaction; systematic method - to determine the main directions of increasing the efficiency of the enterprise advertising industry. According to the results of the research, the author identified the main trends that will prevail in the world and domestic advertising sphere in the coming years, as well as the main directions of improving the efficiency of the advertising industry. The practical significance of research results is that they can be used by advertising companies to improve their own performance, create new sustainable competitive advantages, find strategic opportunities, and more.
\end{abstract}

Keywords: marketing, enterprise, advertising, improvement, direction, efficiency.

\section{Formulation of the problem}

Recently, there have been dramatic changes in the activity of advertising companies, due to significant changes in the environment. The basic tendencies of functioning of the domestic advertising market are largely influenced by these globalization processes and tendencies of development of the world advertising market, since the external environment has a rather significant influence on the activity of advertising enterprises, causes a revision of the bases of their functioning, positive or negative tendencies in their activity. Because of this, there is a real need to adapt the domestic advertising industry and its representatives to global conditions and trends, which is a necessary condition not only for their profitability, but also for their functioning.

\section{Analysis of recent research and publications}

Issues such as the development of advertising companies and the promotion of advertising efficiency have been addressed by such scientists as: W. Arens, G. Armstrong, B. Berman, S. Broadbent, O. Buchinskaya, J. Gelbraith, O. Hochberg, J. Evans, F. Kotler, E. Krykavsky, A. Maslow, G. Pocheptsov, E. Romat, M. Porter, S. Stepanenko, N. Chukhray and others.

\section{Setting objectives}

The purpose of the article is to identify ways to improve the marketing activity of advertising companies.

\section{Outline of the main research material}

Among the major and major global trends of recent times, according to the results of our research, which will be prevailing in the world and domestic advertising sphere in the coming years, we should highlight the following:

First, the emphasis is shifting in the format of the interaction of advertising companies with potential advertisers: if previously the advertising companies initiated such interaction and cooperation, then recently this activity goes to the advertisers who apply to the advertising companies with the offer for participation in the tenders that they are held to 
select the best deal. In this case, it is the advertising companies that, in view of their own capabilities, interest, etc., decide the feasibility of such interaction. According to experts of the All-Ukrainian Advertising Coalition, "Now the advertising market is moving rapidly to make the choice of agency and advertiser a mutual and, very importantly, mutually beneficial process. These tendencies are unlikely to be the case with highly specialized advertising agencies (such as advertising matches, etc.). But this tendency is already characteristic of a sufficiently large number of "wideprofile" advertising agencies that have proven themselves well, both in Kyiv and in the developed industrial regions of Ukraine "[1]. All this causes an increase in requirements for the complexity of advertising agency services. Nowadays, it is not enough for an advertising agency to simply perform the tasks of an advertiser and act as a mediator between him and the media [2]. The current situation in the advertising services market requires the agency to organize comprehensive advertising campaigns for the advertiser (the agency not only needs to develop a media plan for the client's advertising campaign and direct advertising in the media, but also to provide a full range of marketing consulting services, including if necessary to carry out marketing research of the market of production of the client, to determine the positioning of the products of the company - the customer of advertising and its competitors, to analyze you are the consumers of the products of the advertiser and make a portrait of them, together with the advertiser to develop marketing strategy and tactics for the further promotion on the market of its products, and only then proceeding from the general goals and objectives of the client's marketing program, to develop the appropriate advertising campaign) [3, p. 624].

Secondly, advertising has grown beyond the limits of a simple advertising tool and has already become a significant socio-cultural institution and tool that is able to exert considerable influence on society in general and its individual groups, in particular, on various aspects of the functioning of society and its representatives. Thanks to advertising, the ideological influence on society, on the formation of stereotypes and rules of behavior of the society and its individual target groups has recently been actively implemented. "Advertising becomes a means of forming taste, stereotypes of behavior, creating new traditions, destroying or creating the moral world of man. In addition to marketing functions, advertising forms certain behaviors and imposes on consumers their own, often alien to them values, changes the language of society, modifying it in accordance with the "creative" findings of advertisers. Modern advertising is often openly manipulated by the public consciousness, becoming a tool for social control, a means of forming public opinion. Advertising does not simply address any message to the target group - it prescribes the normative parameters and principles of functioning of this group, forms it, makes it legitimate in the structure of public consciousness, etc. "[4].

Third, further digitization of advertising activities and the spread of automation and use of various software technologies in the activity, which contributes to a more efficient use of time and satisfaction of the clients of advertising companies, reducing the number of employees involved and minimizing other costs, etc. Developed technologies are designed to supplement and sharpen people's creative talents, freeing up time spent on routine tasks, such as completing advertising orders [5].

Fourth, the share of mobile and Internet advertising in the overall structure of advertising, whether it is social networks or any other Internet resources, becomes evident. These destinations use new targeting capabilities, otherwise they use data to help sellers get a single image of a potential customer on all screens. After all, it is the cross-screen marketing strategy that will ensure the highest returns for sellers [5].

According to the survey, which was carried out among the specialists of the advertising sphere on the tendencies of development of the advertising and communication market of Ukraine, the following features of the further development were established:

1. Improving the quality and usefulness of advertising services, which is made possible by the implementation of foreign technologies and tools.

2. Development of interactive communications and maximum personalization of advertising hits. Companies are investing in CRM systems to reduce the cost of inefficient mass ad campaigns and spend more on targeted consumers. With the development of technology, such systems are becoming available not only to transnational large companies, but also to medium and small agencies. Accordingly, the change in approach to communications shows a dramatic redistribution of advertising budgets.

3. Mobile advertising is one of the main trends in the development of the Ukrainian advertising market.

4. Thanks to the latest technologies, advertising becomes, on the one hand, individual and on the other interactive. In advertising, innovations are linked to: digital technologies that are more traditional than traditional ones, so more sophisticated, imitating media will be created; virtualization on the Internet with all its capabilities; targeting - adapting to the individual needs of people by studying the history of purchases of specific individuals. 
5. Radio and outdoor advertising, as communication channels, are gradually losing their effectiveness. With regard to the press, the advertiser of a wide variety of print media is beginning to prefer a specialized press whose readership intersects with the intended audience of the advertised product or service.

6. The role of socially responsible advertising is increasing as it allows us to address global issues of importance to society.

7. Some of the print media are being moved to the Internet, which contributes to the development of the following trends: the first is that it is more reliable for advertisers to invest in corporate publications under their control; the second is that some of the released budgets go to the Internet.

8. In line with the increasing popularity of the Internet, the impact of TV advertising will be diminished, as the segment of the audience that is not influenced by TV, radio and other print media is steadily growing. The undervaluation of these active consumers is gradually being adjusted, leading to a redistribution of advertising budgets in favor of less traditional advertising tools.

9. Outdoor advertising is reformatted. Instead of static images, global visual dynamic advertising and video ads on thin screens are gradually being introduced.

10. Shopping malls are turning into entertaining ones, whereby advertising companies will direct their marketing programs on how to advertise places of mass gathering of people, what technologies to attract and keep their attention [6, p. 20].

As for the directions of increasing the efficiency of the marketing activity of the enterprises of the advertising sphere, for this purpose, according to A. Shvets, the advertising agency must today meet the following criteria:

\# "full cycle" agency, where there is a creative department, departments for work with databases and CRM, BTL-units;

* local agencies with a network structure of a full-time kernel with mobile groups of remote jobs; the disadvantage of this type of agency is that a full transition to digital technology will reduce the number of employees;

* Customer + Agency project teams for long-term and complex advertising campaigns. In this case, financial relations with the customer become more transparent, including at the stages of intermediate control, including financial [7, p. 193].

In addition to considering proposals from other scholars to increase the effectiveness of marketing activities of advertising companies, we conducted a survey to determine the priorities of advertising companies and customers of advertising products among these two groups of respondents. All respondents were asked the same questions regarding the priority criteria for choosing an advertising agency, namely: the image of the advertising enterprise; experience in providing advertising services in a specific field; reputation of past and present clients; portfolio of projects implemented by the advertising company; effectiveness of advertising campaigns; terms of execution and timeliness of execution; creativity and creative potential of the advertising enterprise; material-technical base.

In order to increase the coverage and effectiveness of the survey, we have selected 25 domestic advertising companies located in different regions of Ukraine, as well as selected 30 advertising companies that operate in different areas of the economy and different regions of Ukraine. According to the results of the survey we obtained the results presented in table 1 .

Table 1. The results of the survey regarding the choice of advertising company

\begin{tabular}{|c|l|c|c|}
\hline $\begin{array}{c}\mathbf{N o} \\
\mathbf{p} / \mathbf{p}\end{array}$ & \multicolumn{1}{|c|}{$\begin{array}{c}\text { Criterion for the choice of advertising } \\
\text { company }\end{array}$} & $\begin{array}{c}\text { Share of respondents- } \\
\text { advertisers, } \\
\mathbf{\%}\end{array}$ & $\begin{array}{c}\text { Share of respondents- } \\
\text { advertising agencies, \% }\end{array}$ \\
\hline 1 & image of advertising company & 7,1 & 17,2 \\
\hline 2 & experience in providing advertising services & 25,4 & 12,3 \\
\hline 3 & reputation of past and present customers & 7,2 & 26,1 \\
\hline 4 & $\begin{array}{l}\text { portfolio of projects implemented by the } \\
\text { advertising company }\end{array}$ & 8,1 & 16,9 \\
\hline 5 & the effectiveness of advertising campaigns & 20,5 & 4,3 \\
\hline 6 & timing and timeliness of implementation & 6,6 & 11,3 \\
\hline 7 & $\begin{array}{l}\text { creativity and creative potential of the } \\
\text { advertising company }\end{array}$ & 19,7 & 4,8 \\
\hline 8 & material-technical base & 5,4 & \\
\hline
\end{tabular}


In view of the above, in our opinion, the main directions of increasing the efficiency of the enterprise of advertising sphere should be:

* providing clients with a full range of advertising and marketing services;

\# providing customers with quality, creative and engaging content capable of delivering high performance advertising campaigns;

\# the ability to influence and / or shape the behavior of the society and its individual target groups.

\section{Conclusions from the study}

The directions of increasing the efficiency of the activity of the enterprises of the advertising sphere are obligatory and necessary for their consideration in their daily activities. But they should not be chaotic and aimed at solving oneoff problems and tasks or achieving only operational goals. They should be designed for a long period of activity of the advertising enterprise and implemented in the principles of its management, its strategic and tactical goals, objectives, mechanisms, its marketing strategy, which becomes a necessary prerequisite for the existence of the advertising enterprise, and on which efficiency will depend and the effectiveness of the implementation of directions of effectiveness. marketing activity of any advertising enterprise. It is the presence of a quality marketing strategy, not the availability of many technical equipment and capabilities, is today a prerequisite for the effective activity of the advertising enterprise and its high level of competitiveness over a long period.

\section{References}

[1] Official site of the All-Ukrainian Advertising Coalition (2018), available at: http://www.adcoalition.org.ua/ (Accessed 11 November 2019).

[2] Mironov Y.B. (2007), Osnovy reklamnoyi diyal'nosti [Textbook], Posvit, Drohobych, Ukraine.

[3] Kharchuk O.G., Cherevach S.A. (2017), "Trends in the modern development of the advertising market in Ukraine“, Global and national problems of economy, vol. 20, pp. 622-625.

[4] Buchinskaya O.V. (2018), "Promising directions of advertising market development", Scientific Bulletin of Uzgorod National University, vol. 20, pp. 70-73.

[5] Harvard Business Review (2018), available at: http://www.hbr-russia.ru/prodazhi-i-marketing/marketingovayapolitika/p13097/ (Accessed 09 November 2019).

[6] "Ukrainian Advertising: Looking to the Future (Materials of survey of leading Ukrainian experts)" (2010), Marketing and advertising, vol. 5 (165), pp. 19-24.

[7] Shvets A.I. (2011), "Problems and prospects of development of advertising activity in Ukraine", Bulletin of Khmelnitsky National University, vol. 3, pp. 190-194. 